\title{
'N VERANTWOORDING OMTRENT BOKS
}

Die afgelope jare het daar telkens stemme teen boks opgegaan en is telkens met logiese en onlogiese - maar altyd heftige - stemme daarop geantwoord deur voorstanders van boks. Die opvallende van die saak is dat die aanvalle op boks eintlik maar selde van Christelike en Calvinistiese kant opgaan en dat die verdedigers hulle wel soms in hierdie kamp bevind. Op die oomblik is hierdie saak weer heelwat onder bespreking. In 'n ander verband was die skrywers hiervan die afgelope jaar af en toe met hierdie onderwerp doenig en hierdie artikel gee versamelde inligting en gedagtes weer.

Die mees uitgesproke teenstanders van boks, hetsy in die amateurs- of beroepsvorm, is gewoonlik geneeshere.1) By geleentheid van die Jaarvergadering van die Britse Mediese Vereniging in 1960 het 'n geneesheer (Nelson et al., 1960) 'n mosie ingedien dat die regering gevra word om boks onwettig te verklaar vanweë die fisieke en psigiese skade wat dit veroorsaak. Hierdie medikus het boks beskryf as brutaal, sadisties, degraderend en as gewettigde aanranding. Hy het die mening uitgespreek dat boks die enigste sportsoort is ,in which one man was matched against another for the purpose of battering each other into insensibility and possible cerebral trauma" (p. 14).

Drie liggaamsopvoeders, Kenny, Thacker en Gebhart (1940) het die mening uitgespreek dat die oogmerk by alle offensiewe maneuwers in boks is om die opponent te beseer en dat hoe meer doeltreffend die offensief uitgevoer word, hoe groter is die besering wat opgedoen word. Die redakteur van die Amerikaanse tydskrif "Industrial Medicine and Surgery" skryf in clieselfde trant oor beroepsboks: „Professional boxing is an industry. Professional boxers are the plyers of the trade. The prime objective of professional boxing is money - for the pugilist, for the manager, for the promotor, for advertisers, for taxes. Only euphemistically is boxing a sport... In no other trade is the product palpably 'injury'. The successful bout is always attended by physical damage. The customer pays for, and demands, injury. With injury the lot of both

1) Sedert voltooiing van hierdie artikel, het die volgende belangwekkende inleidingsartikel verskyn: Bokser en geneesheer. S.A. Tydskr. Geneesk., 1964, 38, 879-880. 
participants, the winner is he who best survives injury. Human injury is the sorriest product ever turned out by any industry" (Inleidingsartikel, 1951, p. 571).

\section{Gevolge van boksbeserings.}

Die aard en gevolge van hierdie beserings is velerlei. Die belangrikste gevolg is die dood van die beseerde, 'n gebeurtenis wat met pynlike reëlmatigheid voorkom. Op 25 Maart 1963 het die S.A.U.K. die volgende berig uitgesaai: „Die redakteur van die Amerikaanse bokstydskrif, RING, sê dat nagenoeg 450 boksers in die tydperk 1900 tot 1962 na gevegte beswyk het. Volgens nie-amptelike raming kom die aantal sterfgevalle in die bokskryt sedert die Tweede Wêreldoorlog op digby 200 te staan". Die tempo het dus in die afgelope sowat twintig jaar geweldig versnel.

Etlike mediese skrywers meld ook sterfgevalle. Jokl (1941) - wie se Suid-Afrikaanse monografie wêreldwyd aandag geniet het - haal Flint aan wat in 1920 genoem het dat 124 sterfgevalle tot op daardie datum voorgekom het. Hyself gee 'n lys van 43 gevalle wat tussen 1921 en 1940 gerapporteer is (pp. 161-162). Critchley (1957) haal aan dat Steinhaus in die vier jaar voor 195042 professionele boksers getel het wat aan beroepsbeserings oorlede is. Vir Australië het Refshauge (1963) 10 gevalle gedurende die jare 1922 tot 1962 vermeld (wat, na sy berekening, neerkom op ongeveer een sterfgeval per 10,000 gevegte, professioneel plus amateur). Gonzales (1951) het vir New York-staat een-en-twintig sterfgevalle vermeld vir die tydperk 1918 tot 1950 (22 jaar), terwyl McCown (1959) vir die sewejaartydperk van 1945 tot 1952 sewe sterfgevalle in die beroepsgeledere in dieselfde staat vermeld het. In Suid-Afrika het twee beroepsboksers hulle dood in die kryt ontmoet, naamlik Jimmy Elliot en Hubert Essakow.

$\mathrm{Na}$ aanleiding van vyf sterfgevalle as gevolg van beroepsboks binne drie jaar in New York-staat, is die mening in die bogemelde inleidingsartikel uitgespreek dat: „That number of deaths, percentage wise - not in a single mishap such as is the misfortune of some industries, but in five distinct incidents - would have closed many an industry until due safeguards provided some promise of no further catastrophes" (1951, p. 571).

Sterfgevalle as gevolg van boksbeserings kom veral in die beroepsgeledere voor, waar die uitklophou die sensasiewek- 
kende klimaks is waarna gestreef word. Dood tydens amateurgevegte kom egter ook voor. Critchley (1957) meld 28 sterfgevalle wat in die amateurgeledere voorgekom het. Ander verslae in hierdie verband is byvoorbeeld dié van Blonstein (1962), Nelson et al. (1960) en Paul (1957), wat sterfgevalle as gevolg van beserings tydens amateurgevegte in Engeland, Skotland, Denemarke, die V.S.A., Hongarye, asook een in Suid-Afrika meld. Die geval van Nicky Erasmus onlangs was ook in hierdie geledere. Hierdie sterftes onder amateurs is nie so seldsaam as wat dit mag voorkom nie. Stewart-Gordon (1960) meld bv. sterfgevalle op 1 en 12 Desember 1959, en op 17 en 27 April 1960 - betreklik kort op mekaar!

Aangesien die uitklophou die mees beslissende uitslag by 'n geveg is, word gesoek na geleenthede om kwesbare plekke aan die liggaam so hard en so dikwels moontlik te tref. In karate word houe op die kwesbaarste plekke as "doodhoue" beskou, dit wil sê, dit is moontlik om, wanneer nodig ter wille van selfverdediging, 'n mens op dié besondere plekke te dood, selfs met 'n ligte hou. Sommige van hierdie punte is, byvoorbeeld, op die neusbrug, reg onder die neus op die bokaak, teen die slukderm en teen die nekslagare, reg bokant die hart en op die solar plexus. Die genoemde punte is egter ook die mikpunte van boksers - nou egter nie ter wille van selfverdediging nie, maar ter wille van sport.

Die bokshandskoen beskerm die opponent in 'n sekere mate teen noodlottige houe op byvoorbeeld die solar plexus, omdat die groot handskoen nie so diep tussen die weefsels kan indring as byvoorbeeld die kaal hand of voet van die karatebeoefenaar nie. Aan die ander kant verhoog die handskoen die trefkrag van die vuishou. Houe op die hart en die gesig word beslis gevaarliker namate die gewig van die handskoen toeneem.

Die minimum gewig van die bokshandskoen is ses onse. Professionele boksers gebruik handskoene wat tot veertien onse weeg. Wanneer ses onse by die radius van ongeveer twee voet van die arm gevoeg word, word die slaankrag aansienlik vergroot. Hoe verder die arm geswaai kan word, hoe vinniger sal die hand beweeg en des te harder sal die hou wees. Die onervare bokser kan nie so goed van hierdie voordeel van die handskoen gebruik maak as die ervare bokser nie, aangesien dit 'n groter kragsinspanning en fyner tydsberekening verg. 'n Voormalige swaargewigbokskampioen van die wêreld, Mar- 
ciano, se vuishou het egter 'n trefkrag van nagenoeg 2,000 pond gehad. 'n Goed geplaaste vuishou van hierdie intensiteit kan geweldige skade aan die menslike liggaam berokken.

'n Verdere saak wat dus ernstige oorweging verdien, is dié van nie-fatale beserings. Volgens Meyers (1950) is die kans op 'n ernstige besering in boks nagenoeg 3\%. Hy het egter verder bevind dat die persentasie ernstige beserings in die bokskryt by kollegestudente sedert 1939 tot 1948 met ongeveer 33\% toegeneem het.

Sigbare wonde en beserings, wat ook blywende sigbare letsels nalaat, is algemeen en as vanselfsprekend aanvaarde gevolge van boks. In 'n artikel oor die behandeling van skeur. wonde by boks skryf Millard: „What begins as a small laceration becomes a target which soon will be torn open wider with jabs and thumbs. It provides the red of 'a flag waved in front of the bull'. Even the relatively mild-mannered Floyd Patterson has admitted he would be forced to go after a cut in a close fight" (1963, p. 296). As deel van sy pleidooi daarvoor dat wonde tussen rondes toegewerk moet word, wys dié skrywer daarop hoe ,the gaping wound is continuously bathed in sweat and punched with dirt and bacteria" (p. 296). Skeurwonde is veral mikpunte as hulle in die omgewing van die ooglede en wenkbroue voorkom, omdat die bloed in die oë die bokser se gesigsvermoë belemmer.

Talryke ander beserings kom ook voor. Soos Kenny et al. (1940) opgemerk het, is die probleem dat: „The type of injuries most common are insidious in nature and in many cases are not recognized by either participants or coaches".

Critchley (1957) en Refshauge (1963) verwys na die bevindinge van oogkundiges in verband met ' $n$ verskeidenheid van oogbeserings, waaronder losgeraakte retina (wat slegs in uitsonderlike gevalle sjirurgies herstel kan word), kolsgewyse degenerasie van die choroïed (aarvlies), katarak (oogpêrel), geskeurde iris, verskuiwing van die lens, asook steurnisse en selfs verlamming van akkommodasie. Critchley merk op: „Just how common they are in the course of a boxing career has not been made clear" (1957, p. 358), terwyl Refshauge meen dat hulle, minstens in Australië, inderdaad skaars is. Blindheid of gedeeltelike verlies van gesig skyn egter nie onbekend te wees by oud-boksers nie. Stewart-Gordon (1960) noem die name van sewe gewese kampioene wat so getref is. Misvormde 
oogbanke, ore en neus is die kenmerke van die ou bokser se voorkoms. Millspaugh (1937) beskryf die stem van boksers wat "hoarse, rasping, husky, coarse, or thick" mag word as gevolg van strottehoofs- en neusbeserings. Verskeie ondersoekers (o.a. Amelar \& Solomon, 1954; Flood, 1959; Kleiman, 1958; McCown, 1959) wys op nierbeserings, wat aangedui word deur bloed en eiwit in die urine, en wat chronies mag word. Jokl (1941) meld dat ' $n$ hou op die maag uitgebreide skeuring in die niere kan veroorsaak.

Mees ingrypend van al is egter beserings aan die brein van die bokser, wat nie sigbaar is nie en die gevolge waarvan selfs eers veel later merkbaar mag word. Aangesien uitklophoue maklik op die ken, op en onder die neus en onderkant die oor gegee kan word, word baie houe na die kop gemik. Die skudding wat deur so 'n hou veroorsaak word, word direk van die skedel af op beide die laere en hoëre sentra van die brein na binne oorgedra. Benewens akute lewensgevaar, hou hierdie skudding die moontlikheid van chroniese skade in. Die uitwerking van houe teen die kop is kummulatief en is dik. wels nie op 'n vroeë stadium herkenbaar nie. Oor die moontlikheid van vele klein bloedingkies oral in die brein, wat as 'n moontlike gevolg van houe teen die kop beskryf is, is daar nie eenstemmigheid nie. (Blonstein \& Clarke, 1957; Critchley, 1957; Martland, 1928). Die meer resente verklaring van die chroniese belemmering is in terme van selafsterwinge. Blonstein en Clarke (1957) haal ondersoekinge op diere aan wat daarop dui dat 'n hou wat hard genoeg is om bewusteloosheid tot gevolg te hê, sowel as ander harde houe, weefselveranderinge in die vorm van afsterwing van senuweeselle tot gevolg het. Hulle vervolg: „It follows that if these changes take place in the human brain, repeated stimuli of the same nature will cventually bring about clinically detectable brain degeneration such as that seen in the professional pugilist after a long and misguided career" (p. 363). Hulle verwys in hierdie verband na 'n geval van witstofdegenerasie by 'n ,very severe closed head injury" wat tevore gerapporteer is.

Letsels wat op hierdie uyse ontstaan is permanent, aangesien daar nie plaasvervangers kom vir breinselle wat doodgaan nie. Hierdie letsels kan elektro-ensefalografies (EEG) ondersoek word en verskeie ondersoekers (o.a. Busse \& Sil. verman, 1952; Critchley, 1957; Nelson, 1964; Nesarajah et al., 1961) het bevindinge in hierdie verband gerapporteer. Busse 
en Silverman (1952) het by nege uit 24 (37.5\%) beroepsboksers vermeerderde voorkoms van EEG-disritme gevind. Hier te lande het Nelson (1964) 18 blanke beroepsboksers ondersoek en gevind dat ses van hulle matige tot ernstige EEG-abnormaliteit getoon het. Ook by amateurboksers is abnormaliteite op hierdie wyse aangetoon. Nesarajah et al. (1961) het by 30 uit $50(60 \%)$ amateurboksers in Ceylon spontane uitbarstinge van versteurde EEG-aktiwiteit gevind, teenoor ses uit 75 (8\%) by hulle nie-bokser kontrolegevalle. Nelson meld dat algemeen aanvaar word dat die persentasie abnormale EEG's by normale groepe tussen 5 en $15 \%$ lê. Dit is dus duidelik dat die voorkomssyfer by boksers aansienlik hoër is as wat normaalweg verwag sou word.

Die gevolge van sodanige breinletsels mag wissel van tydelik tot blywend en van gering tot uiters ingrypend. Verwardheid, disoriëntasie, sufheid, verminderde bewussynspeil en periodes van geheueverlies - selfs sonder dat daar 'n waar. neembare uitklop was - is bekende tydelike nagevolge van houe teen die kop. Wisselende grade van permanente versteuringe is egter ook beskryf. Nesarajah et al. (1961) het definitiewe veranderinge in houdinge teenoor werk opgemerk by studenteboksers, d.w.s. amateurs. Blonstein haal 'n Skotse mediese korrespondent van die Internasionale Amateurboksvereniging as volg aan: „Unfortunately I have seen amateurs whom I know had undergone deterioration since the beginning of their boxing career. In amateurism the changes are never as severe as in professionalism, in fact a clinical examination would reveal no objective sign, it is only by knowing the boys for a time that I have been able to note the change" (1962, p. 181). Belemmeringe van die geheue, onvermoë om te konsentreer, swak oordeelsvermoë en humeurigheid is van die ernstiger chroniese nagevolge wat al beskryf is. Hierby kom fisieke simptome met ' $n$ duidelik herkenbare neurologiese grondslag, soos hoofpyn, swak gesig, bewerigheid, duiseligheid en versteurde spierkoördinasie. Laasgenoemde mag merkbaar word in 'n skuifelende of steierende manier van loop.

Die psigiese steurnisse kan so ingrypend word dat die oudbokser as 'n sielsieke gehospitaliseer moet word. Die presiese aard van 'n siektebeeld wat as „punch drunkenness", „traumatiese (progressiewe) ensefalopatie" of "dementia pugilistica" bekend staan, is die onderwerp van 'n mate van twisgeskryf onder medici. McCown (1959) meen dat so 'n toestand 
nie bewese is as ' $n$ neurologiese sindroom wat kenmerkend is van boksers en wat veroorsaak is deur boks nie. Verskeie ander skrywers (w.o. Blonstein, 1962; Critchley, 1957; Grewel, 1955; Martland, 1928; Millspaugh, 1937) het egter die bestaan daarvan erken en duidelike beskrywings gegee. Critchley en Grewel meen albei dat die sindroom in vier hoofvorme onderverdeel kan word.

Die volgende aanhaling gee 'n bondige maar duidelike beskrywing van die algemene beeld: „The symptoms and signs of a punch-drunk state are variegated, but there are certain clinical features which underlie all the diverse patterns of the disease. As a rule, gradual evolution of mental and physical anomalies marks the insidious onset of the encephalopathy. Among mental symptoms there is the slow appearance of a fatuous or euphoric dementia with emotional lability. The victim displays but little insight into his deterioration. Speech and thought become progressively slower. Memory deteriorates considerably. In Service experience there is a fallingoff both in efficiency and in conduct. There may be moodswings, intense irritability, and sometimes truculence leading to uninhibited violent behaviour. Simple fatuous cheerfulness is, however, the commonest prevailing mood, though sometimes there is depression with a paranoid colouring" (Critchley, 1957, p. 359). Dieselfde skrywer meld ook dat misdadigheid beuys mag wees van snelle persoonlikheidsverandering wat met progressiewe breinbeskadiging gepaard gaan.

Daar is geen bekende metodes om 'n ommekeer in so ' toestand te bewerkstellig nie. Die simptome mag geleidelik vererger, selfs al hou die persoon op met boks. By die beroepsbokser is ophou egter ' $n$ probleem, omdat sy brood dan daarmee heen is. Wat meer is, soos McCown en Stevens skryf: „Let us recognize here that the average professional boxer can only make money if he boxes frequently" (1962, p. 100).

Die geskiedenisse van sulke „vuisvoos" pasiënte toon, volgens verskeie skrywers, opvallende ooreenkomste. Dit volg na jarelange deelname aan boks, waarby beide die totale aantal gevegte en die aantal kere wat die persoon uitgeklop is, met die ernstigheid van die toestand korreleer. Om hierdie redes kom dit by amateurboksers, volgens sommige skrywers, slegs heel selde voor en, volgens andere, glad nie. Om Chritchley weer aan te haal: „It is commoner in second-rate or thirdrate performers than in the intelligent scientific exponent with 
a championship title ... As fighters, the punch-drunk ex-pugilists have been slow on their feet rather than nimble, and notorious as being able to 'take it'. They can perhaps be looked upon as 'sluggers' rather than scientific boxers. Punch-drunken states have been found in fighters of all weights, but most characteristically in small men who had not been particular about the size of their opponents, having often taken on contestants heavier than themselves" (1957, p. 359).

\section{Argumente en teenargumente.}

Wanneer 'n donker prent, soos die voorgaande, geteken word, is die verweer van die voorstanders van boks dadelik dat dieselfde beweringe ook omtrent ander sportsoorte gemaak kan word.

Dat besering en dood ook by ander sportsoorte voorkom, moet dadelik gelyk gegee word. Rugbybeserings is seker die bekendste sportbeserings in ons land, en sterfgevalle as gevolg van rugbybeserings is ongelukkig ook bekend. By haas alle sportsoorte moet met die moontlikheid van besering en lewensverlies rekening gehou word. Hierdie argument word egter ook dikwels ad absurdum deurgevoer om die beserings en fatale ongelukke wat in elke lewensomstandigheid mag voorkom, in te sluit. Daar word byvoorbeeld verwys na die sterftesyfer op die paaie en na binnenshuise ongelukke. Raeburn het geargumenteer: „Would anybody declare golf illegal because of the danger of falling at the nineteenth hole?" (Nelson et al., 1960, p. 14).

Verskillende teenargumente moet geopper word. Die eerste daarvan volg op 'n geredelike erkenning van fatale en niefatale beserings by ander sportsoorte, maar met die vraag of dit dan gronde is om boks mee te regverdig. Dit kom daarop neer dat die oortreding van 'n gebod nie geregverdig kan word deur ander oortredings van dieselfde gebod te opper nie. Ten opsigte van die probleem van sportbeserings, behoort elke sportsoort op 'n verantwoordelike wyse deur die deelnemers en voorstanders daarvan beoordeel te word. Indien verkeerde tendense daarby opgemerk word, behoort hulle met alle mag voorkom te word. Indien dit nie kan gebeur nic, is die enigste weg wat die werklik verantwoordelike deelnemer kan inslaan, om hom daaraan te onttrek. Bloot ter wille van sport en ontspanning - van watter aard ook al - mag geen volwasse mens homself van toerekenbaarheid en verantwoordelikheid probeer 
losmaak nie. Dit doen slegs kinders en adolessente.

Die tweede teenargument gaan in terme van relatiewe syfers. Voorstanders van boks meld telkens in absolute aantalle dat verskeie ander sportsoorte meer beserings en sterftes veroorsaak as boks. Die argumente behoort egter in terme van die aantal beserings in verhouding tot die aantal deelnemers gevoer te word. Hierdie tipe vergelykende statistieke is mocilik bekombaar. Gonzales (1951) het, in terme van die absolute aantal, meer sterfgevalle vir bofbal as vir boks gerapporteer (vir die tydperk 1918 tot 1950 in New York-staat) en was van mening dat in verhouding tot die aantal deelnemers dit ook die geval was. Volgens Steinhaus (aangehaal deur Stewart-Gordon) is boks gevaarliker as Amerikaanse voetbal: „Based on deaths per number of participants, boxing is 83 times more deadly than high-school footbal, 50 times more deadly than college football" (1960, p. 71). Grewel meld etlike sportsoorte, benewens boks, waarby skudding van die brein betreklik algemeen voorkom, maar merk dan op: „Traumatische psychotische verschijnselen zijn echter zeldzaam hierbij; cen post-commotionele psychose evencens" (1955, p. 166). Voordat die getalsargument op 'n suiwer basis deurgevoer kan word, moet volledige en duidelike syfers in persentasievorm verkry word - deur beide voorstanders en teenstanders van boks.

Die derde, en belangrikste, teenargument betref die intensies van die deelnemers. Wanneer beserings en dood by ander sportsoorte voorkom, is dit meestal (nie altyd nie) die gevolg van werklike ongelukke. Dit is nie intensionele beserings nie. Allermins kan daar sprake wees van opsetlikheid by ongelukke op pad of in die loop van die alledaagse lewensgang. By boks, daarenteen, is die bewuste, vooropgesette doel om die opponent op so 'n wyse te lyf te gaan dat hy dit nie kan deurstaan nie of dat hy sy bewussyn verloor. Daar word wetenskaplik beplan om die kwesbaarste liggaamsdele wat onder die reëls toegelaat word, raak en reg te slaan. Deur langdurige oefening word die kuns stelselmatig verfyn om die opponent so goed moontlik uit aksie te stel. Boksapologete, soos dic Voorsitter van die Transvaalse Beheerraad oor Beroepsboks, mnr. George Owen-Davis, het die mening gelug dat: „... it would be below the belt to suggest that men have died in the ring because their opponents had intent to kill" (Cape Times, 1963). Verseker beplan geen bokser om sy teen- 
stander dood te slaan nie. Indien dood egter die gevolg is van 'n uitklophou, en indien die uitklophou die eindresultaat is van oefening en beplanning, is daar 'n ketting van oorsaak en gevolg wat tot ernstige verantwoording roep.

'n Ander grond waarop boks verdedig word, is dié van 'n min of meer noodsaaklike vorming in selfverdediging. Vir hierdie doel kan minder gevaarlike en selfs meer doeltreffende verdedigingskunste egter waarskynlik gevind word. As middel van selfverdediging is boks nie so doeltreffend as byvoorbeeld stoei, judo of karate nie. Dit geld veral in gevalle waar die persoon bedreig word deur iemand met 'n mes, knuppel of vuurwapen. Wanneer 'n vaardige bokser teen 'n vaardige stoeier te staan kom, het laasgenoemde 'n groter kans om die geveg te wen as die bokser. Teen die kenner van karate is die bokser heeltemal weerloos.

Verwant aan die voorgaande, is die argument dat boks bevorderlik is vir algemene persoonlikheidsontwikkeling, veral vanweë die vermeerderde gevoel van selfvertroue wat die besef van „ek kan vir myself sorg" meebring. Die karaktervormende waarde van deelname aan boks as sportsoort word ook dikwels beklemtoon. Keefer (1951) het hierdie aspekte oorweeg en tot die gevolgtrekking geraak dat boks geen unieke opvoedkundige voordele bied wat nie ook uit ander sportsoorte geput kan word nie. Ook Jokl was van mening dat: „There is not the slightest doubt that all the educational benefits derived from boxing can be achieved equally well through sports which do not constantly endanger health and efficiency of the central nervous system" (1941, p. 159). As boks ten opsigte van opvoedkundige voordele hoogstens gelyk staan met ander sportsoorte en as laasgenoemde minder gevaar van ernstige besering inhou, is die rigting van die keuse duidelik.

In hierdie verband merk Kenny et al. (1940) op: „Instructional classes in boxing are not particularly dangerous, but it is impossible to justify teaching an activity and at the same time to advise students against participation in the activity taught". Hulle is dan ook, na 'n breedvoerige ondersoek en beredenering, van mening dat boks nie in die sportprogram van 'n opvoedkundige inrigting ingesluit behoort te word nie, nòg as deel van 'n leerplan nòg as buitemuurse aktiwiteit.

Betreffende fisieke voordele van boks - wat dikwels deur voorstanders aangeprys word - is 'n ondersoek wat Landiss (1951) op studente uitgevoer het, van belang. Alle eerstejaar- 
studente aan 'n landboukollege is in agt groepe ingedeel. Elkeen van hierdie agt groepe het vir 'n semester lank drie keer per week vir 'n uur aan 'n bepaalde sportsoort geoefen. Die volgende agt sportsoorte is gekies: stoei, tennis, volleybal, swem, gimnastiek, gewigoptel, boks en fiksheidsoefeninge. Nadal die groepindeling gemaak is, is die studente aan 'n toets vir die meting van die liggaamlike fiksheid en 'n toets vir die meting van motoriese vaardigheid onderwerp. Gedurende dié semester het die studente nie aan ander sportaktiwiteite deelgeneem nie. $\mathrm{Na}$ die oefentydperk van ses maande is bevind dat die boksers, die swemmers en die tennisspelers die minste verbetering in die toets vir liggaamlike fiksheid getoon het. In die toets vir motoriese vaardigheid het die boksers en die swemmers die minste verbeter. Die gimnaste en die stoeiers het, oor die algemeen, die beste fisieke vooruitgang getoon. Volgens hierdie ondersoek, is boks dus nie so 'n geskikte oefenmetode as byvoorbeeld stoei nie, en kan daar nie 'n besondere sterk saak vir boks as metode ter bevordering van fisieke ontwikkeling uitgemaak word nie.

'n Aspek wat nog in die verbygaan die aandag moet geniet, is die feit dat boks ' $n$ toeskouersport is. Heel dikwels, beslis by beroepsgevegte, is die toeskouers sensasiebelus. 'n Tegniese uitklophou of wen met punte val nie besonder in die smaak van die toeskouers nie. Refshauge skryf in dié verband: „I am sure that the psychological factors that stimulate the large attendances at major boxing tournaments would be unsatisfied if the possibility of a knock-out was eliminated. In that case, if attendances fell, the professional side of the sport would cease to flourish" (1963, p. 612). Die uitjouery van die teenstander deur toeskouers en die tierende aanmoediging van die gunsteling in dikwels bloeddorstige uitdrukkings, dien seker ook opgemerk te word.

\section{Skrifgelowige verantwoording.}

Wanneer gegewens omtrent boksbeseringe en die gevolge daarvan onder die oë gesien word, kan die Christenmens nie anders as om dit met die sesde gebod in verband te bring nie. Die vraag dring hom na vore: „Is boks 'n sportsoort wat toelaatbaar is in die lig van die gebod teen doodslag?"

Hierdie gedagte is deur die reedsvermelde mnr. OuenDavis by geleentheid as „ridiculous" en ,absurd" beskryf. Daar is inderdaad baie mense wat met hom saamstem, deels omdat 
die gebod: „Jy mag nie doodslaan nie" uiters eng opgeneem word, en deels omdat religie te eng opgeneem word. Volgens 'n koerantberig (Cape Times, 1963) was mnr. Owen-Davis van mening: „It is insidious to drag religion into sport".

Die eise van die sesde gebod word in clie antwoord op Vraag 105 van die Heidelbergse Kategismus, met Skrifverwysings, as volg uiteengesit: „Dat ek my naaste nie met gedagtes, en ook nie met woorde of enige gebaar en nog minder met die daad, deur myself of deur ander mag onteer, haat, wond of doodmaak nie; maar dat ek alle wraakgierigheid moet aflê; ook myself nie mag wond of moedswillig in enige gevaar mag begewe nie; daarom dra die owerheid ook die swaard om die doodslag te weer".

As hierdie implikasies in verband met boks gebring word, kan die standpunt nie uitbly dat dit 'n sportsoort is wat vir die Christen ontoelaatbaar is nie. Die persoon wat aan 'n boksgeveg deelneem, moet insien en besef dat hy sodoende besig is om sy naaste met gedagtes, woorde, gebare en dade te onteer. Hy moet besef dat hy eintlik nie anders kan as om sy naaste sigbaar of nie-sigbaar te wond nie en dat hy hom beslis self in die gevaar van verwonding begewe. Op grond van die ervaring van andere, moet hy ook besef dat hy in die uiters werklike gevaar verkeer om 'n naaste te dood en dat hy homself in lewensgevaar begewe. By dit alles moet daar ook sprake wees van moedswillige skepping van hierdie geleenthede, omdat daar geen noodsaaklikheid bestaan op grond waarvan dit geregverdig kan word nie. As die mens homself en sy medemens sien as skepsels van God, sy eie en sy medemens se liggame as tempels van God, dan kan hy nie ontspanning en tydverdryf soek in ' $n$ sport waarby beseer en platslaan die oogmerke is nie.

Wat kan gedoen word?

Die eerste saak wat hier oorweeg moet word is dié van beroepsboks. Dit is geen sport in die gewone sin van die woord nie. Dit gaan om die maak van geld deur die toedien van beserings wat wel bedoel is om tydelik te wees, maar wat ook veelal blywend word, hetsy onmiddellik by toediening, hetsy kummulatief oor die jar.. Die beserings en nagevolge van beserings wat hierbo beskryf is, kom telkens in hulle grofste en uiterste vorms voor by beroepsboksers. Dit is ook hier waar die doodsgevaar die grootste is. Geeneen van die argumente wat boksapologete omtrent die veronderstelde waarde 
van die vuisvegkuns opper, gaan in verband met beroepsboks op nie. As daar dan op Skrifgronde gestel word dat die Owerheid die swaard dra om doodslag te weer, behoort daar ook uit die kamp van Skrifgelowiges 'n geroep tot die Owerheid op te gaan om hierdie beroep in die ban te doen.

Dan bly daar nog amateurboks oor. Uit bloot humanistiese oorweginge gaan daarteen ook telkens stemme op oor die hele wêreld. Streng maatreëls word getref om amateurboks te beveilig en dergelike reëls is sekerlik lofwaardig. Die ervaring leer egter telkens dat daar geen wesentlike verskil is tussen die amateur- en die beroepsvorm nie. Die gevare is slegs gradueel verskillend. Daarom kom dit voor of alle pogings om amateurboks uit skole, universiteite en dergelike plekke vir jongmense te weer, gesteun moet word - met dieselfde aansporings as dié ten opsigte van beroepsboks.

Aangesien dit egter ' $n$ saak is wat eintlik nie met wet en regulasie in geheel verban sal kan word nie, skyn dit 'n saak te wees wat met oorreding bekamp moet word. Pogings behoort aangewend te word om vaders en moeders, maar ook seuns en dogters, te oortuig dat dit 'n onaanvaarbare sportsoort is. By dergelike pogings moet gewaak word teen summiere veroordeling en verbanning, wat slegs weerstand wek. Oorreding sal meer suksesvol wees wanneer dit op inligting en verduideliking gebou word, sodat die voor- en nadele intelligent oorweeg kan word. Positief moet verder in gedagte gehou word die realistiese behoefte aan sport, in die algemeen, en aan oefening ter selfverdediging, in besonder. Dit is dinge wat beslis nodig is en deur kinders en jeugdiges aangeleer kan en moet word. In plaas van net af te keur en te veroordeel, moet positief gesoek word na alternatiewe sportsoorte en ontspanningsaktiwiteite wat wel toelaatbaar en aanbevelenswaardig is.

P.U. vir C.H.O.

D. J. W. Strümpfer en W. J. Putter.

\section{LITERATUURVERWYSINGS:}

Amelar, R. D. \& Solomon, C. (1954). Acute renal trauma in boxers. J. Urol., 72, 145-148.

Blonstein, L. (1962). Enquiry on medical aspects of amateur boxing. $J$. Sports Med. Phys. Fitness, 2, 180-184.

Blonstein, J. L. \& Clarke, E. (1957). Further observations on the medical aspects of amateur boxing. Brit. med. J., No. 5015, 1, 362-364. 
Busse, E. W. \& Silverman, A. J. (1952). Electroencephalographic changes in professional boxers. J. Amer. Med. Assoc., 149, 1522-1525.

Cape Times, 22 November 1963.

Critchley, M. (1957). Medical aspects of boxing, particularly from a neurological standpoint. Brit. med. J., No. 5015, 1, 357-362.

Flood, F. B. (1959). Albuminuria and hematuria in boxers. J. Amer. Med. Assoc., 171, 1678-1679.

Gonzales, T. A. (1951). Fatal injuries in competitive sports. J. Amer. Med. Assoc., 146, 1506-1511.

Grewel, F. (1955). Sport en neurologische afwijkingen. In Jongbloed, J. \& Jongh, J., Sportgeneeskunde. Utrecht: Oosthoek. Pp. 164-169.

Inleidingsartikel (1951). The nation's most dangerous trade - professional boxing. Industr. Med. Surgery, 20, 571-572.

Jokl, E. (1941). The medical aspect of boxing. Pretoria: Van Schaik.

Keefer, R. E. (1951). An evaluation of the educational aspects of boxing as a college activity. Res. Quart. Amer. Assoc. Hlth. Phys. Educ. Recr., 22, 337-344.

Kenny, H. E., Thacker, E. A. \& Gebhart, H. C. (1940). The evaluation of boxing as a college activity. Res. Quart. Amer. Assoc. Hith. Phys. Educ. Recr., 11, 80-93.

Kleiman, A. H. (1958). Hematuria in boxers. J. Amer. Med. Assoc., 168, 1633-1640.

Landiss, C. W. (1951). Influences of physical education activities on motor ability and physical fitness of male freshmen. Res. Quart. Amer. Assoc. Hith. Phys. Educ. Recr., 26, 295-307.

Martland, H. S. (1928). Punch drunk. J. Amer. Med. Assoc., 91, 1103-1107.

McCown, I. A. (1959). Boxing injuries. Amer. J. Surgery, 98, 509-516.

McCown, I. A. \& Stevens, M. A. (1962). Considerations in the management of traumatic injury in professional boxers. J. Sports Med. Phys. Fitness, 2, 99-102.

Meyers, C. R. (1950). The status of boxing in institutions of higher learning. Res. Quart. Amer. Assoc. Hlth. Phys. Educ. Recr., 21, 292-302.

Millard, D. R. (1936). Closure of boxing lacerations between rounds. Arch. Surgery, 86, 295-298.

Millspaugh, J. A. (1937). Dementia pugilistica (punch drunk). U.S. Nav. Med. Bull., 35, 297-303.

Nelson, G. K. Persoonlike mededeling, 14 April 1964.

Nelson, N., Raeburn, B. \& Moloney, G. E. (1960). Boxing. Brit. med. J. Suppl., 2, 14.

Nesarajah, M. S., Seneviratne, K. N. \& Watson, R. S. (1961). Electroencephalographic changes in Ceylonese boxers. Brit. med. J., No. 5229, $866-868$.

Paul, M. (1957). A fatal injury at boxing (traumatic decerebrate rigidity). Brit. med. J., No. 5015, 1, 364-366.

Refshauge, J. G. H. (1963). The medical aspects of boxing. Med. J. Austr., 50th Year - Vol. I, 611-613.

Stewart-Gordon, J. (1960). Death by knockout. Reader's Digest (Amerikaanse uitgawe), November, 70-74. (S.A. uitgawe, effens verkort, Maart 1961, 57-60). 